\title{
PENGARUH LAMA PEMANASAN TERHADAP NILAI KESADAHAN KALSIUM PADA AIR SUMUR GALI ASAL DESA BANTI MURUNG KABUPATEN MAROS
}

\author{
Rahman $^{1}$, Kalma $^{2}$ \\ 1,2Jurusan Analis Kesehatan Poltekkes Kemenkes Makassar
}

Koresponden : ramangcarallang@ gmail.com

\begin{abstract}
ABSTRAK
Penelitian ini dilatarbelakangi oleh terjadinya endapan billa air dibiarkan dalam beberapa hari dan timbulnya lapisan kerak pada wadah pemanas air apabila air dipanaskan. Tujuan penelitian ini adalah untuk mengetahui pengaruh pemanasan terhadap nilai kesadahan kalsium pada air sumur gali asal Desa Bantimurung Kabupaten Maros. Jenis penelitian ini bersifat eksperimen semu yang dilaksanakan secara laboratorik dimana jumlah sampel yang digunakan dalam penelitian ini sebanyak 3 sampel dengan menggunakan teknik pengambilan sampel secara acak sederhana. Metode yang digunakan didalam penentuan nilai kesadahan kalsium adalah metode Kompleksometri dengan menggunakan Larutan baku $\mathrm{K}_{2}$ EDTA 0,01 M. Dari hasil penelitian dengan menggunakan uji anova maka didapatkan hasil bahwa $F_{\text {hitung }}(19,07)>F_{\text {Tabel }}(3,48)$, berarti $\mathrm{H} \alpha$ diterima, artinya terdapat pengaruh yang signifikan terhadap nilai kesadahan kalsium pada air sumur gali dengan variasi waktu pemanasan (pendidihan) 0 menit, 2 menit, 4 menit, 6 menit, dan 8 menit.
\end{abstract}

Kata Kunci : Kesadahan kalsium, Pemanasan, Air Sumur Gali

\section{PENDAHULUAN}

Air merupakan kebutuhan yang sangat utama bagi kehidupan manusia, oleh karena itu jika kebutuhan akan air belum terpenuhi baik secara kuantitas maupun kualitas, maka akan menimbulkan dampak yang sangat besar terhadap kehidupan sosial dan ekonomi masyarakat. Terutama yang erat kaitannya dengan kesehatan (Said IN, 2010).

Pengelolaan sumber daya air yang kurang baik dapat menyebakan kekurangan air, Indonesia telah memiliki undang-undang yang mengatur sumber daya air sejak tahun 2004, yakni Undang Undang nomor 7 tahun 2004 tentang Sumber Daya Air. (Anonim, 2013)

Salah satu parameter kimia dalam persyaratan kualitas air adalah kandungan unsur ion $\mathrm{Ca}^{2+}$ dalam air yang keberadaannya biasa disebut kesadahan air. Kesadahan adalah istilah yang digunakan pada air yang mengandung kation penyebab kesadahan. Tingkat kesadahan di berbagai tempat perairan berbedabeda, pada umumnya air tanah mempunyai tingkat kesadahan yang tinggi. Hal ini terjadi, karena air tanah mengalami kontak dengan batuan kapur yang ada dilapisan tanah yang dilalui air (Said IN, 2010). 
Kecamatan Bantimurung Kabupaten. Maros merupakan rentetan salah satu pegunungan karst (kapur) di Indonesia. Kebiasaan masyarakat Kec. Bantimurung dalam mengkonsumsi air minum adalah dengan menggunakan air sumur gali yang terdapat di sekitar rumah-rumah masyarakat. Air sumur tersebut juga digunakan untuk keperluan mandi dan mencuci yang belum diketahui standar kualitas air dari segi fisika, kimia, mikrobiologi. Kedalaman sumur kira-kira 10-20 meter. Pada saat direbus, air akan menghasilkan kerak di sekitar panci. Hal tersebut diduga kesadahan air cukup tinggi. Oleh karena itu, air harus diendapkan dan disaring terlebih dahulu sebelum digunakan sebagai air minum atau memasak. Gejala kesadahan air yang tinggi juga dapat diamati dari sabun yang sulit berbusa sehingga masyarakat harus menggunakan banyak detergen. Sedangkan batas kesadahan yang masih diperbolehkan berdasarkan Peraturan Menteri Kesehatan RI Nomor 907/MENKES/SK/VII/2002 tentang syarat-syarat pengawasan air minum yaitu $500 \mathrm{mg} / \mathrm{l}$.

Air sadah digolongkan menjadi dua jenis berdasarkan jenis anion yang diikat oleh kation $\left(\mathrm{Ca}^{2+}\right.$ dan $\left.\mathrm{Mg}^{2+}\right)$, yaitu air sadah sementara dan air sadah tetap. Air yang mengandung kesadahan sementara yakni garam $\mathrm{Ca}\left(\mathrm{HCO}_{3}\right)_{2}$ dan $\mathrm{Mg}\left(\mathrm{HCO}_{3}\right)_{2}$ jika dipanaskan maka akan membentuk senyawa $\mathrm{CaCO}_{3}$ dan $\mathrm{MgCO}_{3}$. Garam $\mathrm{MgCO}_{3}$ mempunyai kelarutan yang lebih besar dalam air panas, namun semakin rendah temperaturnya kelarutannya semakin kecil bahkan kelarutannya lebih kecil dari $\mathrm{MgCO}_{3}$, sehingga pada air panas sebagian $\mathrm{CaCO}_{3}$ mengendap dan pada air yang telah dingin pengendapannya lebih banyak lagi. Terjadinya endapan ini memungkinkan hasil perhitungan kesadahan menjadi lebih rendah.

Bedasarkan latar belakang masalah tersebut diatas, maka peneliti telah melakukan penelitian yang tentang pengaruh lama pemanasan terhadap nilai kesadahan kalsium pada air sumur gali di Kecamatan Bantimurung Kabupaten Maros

\section{METODE}

Jenis penelitian ini merupakan eksperimen semu yaitu berupa penentuan tingkat kesadahan pada air sumur gali setelah dipanaskan guna mengetahui tingkat kualitas air dari syarat kimia. Penelitian dilaksanakan di laboratorium Kimia Analitik jurusan Analis Kesehatan Politeknik Kesehatan Makassar pada bulan Februari-Maret 2019.

Sampel penelitian ini adalah air sumur gali yang dikonsumsi oleh masyarakat di Kec. Bantimurung sebanyak 3 sampel dengan teknik pengambilan sampel dilakukan secara random sampling.

Alat penelitian yang digunakan dalam penelitian ini adalah beaker glass, botol penampung sampel, Penanggas air, buret, corong, karet penghisap, labu erlenmeyer, labu takar, neraca analitik, pipet volume, sendok tanduk, dan statik buret. Sedangkan bahan penelitian yaitu : larutan induk EDTA 0,1 M (ditimbang 18,612 gram EDTA kemudian dimasukkan ke dalam labu takar 500ml, lalu dilarutkan dengan menggunakan aquades sampai 
tanda). Dari larutan induk EDTA 0,1 M, dibuat larutan baku EDTA 0,01 $\mathrm{M}$ (dipipet $50 \mathrm{ml}$ larutan induk DTA $0,1 \mathrm{M}$ ke dalam labu takar 500ml, kemudian diencerkan dengan menggunakan aquades sampai tanda). Kemudian distandarisasi dengan menggunakan $\mathrm{CaCO}_{3} 0,01 \mathrm{M}$, Larutan baku $\mathrm{CaCO}_{3} \quad 0,01 \quad \mathrm{M}$ (ditimbang 0,25 gram $\mathrm{CaCO}_{3}$ kemudian dimasukkan ke dalam labu takar $250 \mathrm{ml}$, lalu dilarutkan dengan menggunakan aquadest sampai tanda), Larutan buffer $\mathrm{pH} 10$ (dipipet $57 \mathrm{ml} \mathrm{NH}_{4} \mathrm{OH}$ pekat, ditambahkan dengan 7,0 gram $\mathrm{NH}_{4} \mathrm{Cl}$ lalu ditambahkan aquades $100 \mathrm{ml}$ ), Indikator Erichrome Black T (EBT), dan $\mathrm{NaOH} 2 \mathrm{~N}$ (ditimbang 8 gram $\mathrm{NaOH}$ kemudian dimasukkan ke dalam labu takar $100 \mathrm{ml}$, lalu dilarutkan dengan menggunakan aquades sampai tanda).

Prosedur Kerja

a. Perlakuan Sampel: Sampel A yang telah diambil kemudian dibagi menjadi 5 bagian kedalam Erlenmeyer kemudian diberi label a1, a2, dan a3, a4, a5. Sampel a1 dipanaskan sampai tepat mendidih( 0 menit), sampel a2 dididihkan selama 2 menit, sampel a3 dididihkan selama 4 menit, sampel a4 dididihkan selama 6 menit dan sampel pada Erlenmeyer a5 dididihkan selama 8 menit. Setelah dipanaskan didinginkan terlebih dulu, kemudian dititrasi dan dicatat hasilnya. Dilakukan perlakuan yang sama pada sampel B dan seterusnya.

b. Standarisasi EDTA 0,01 M dengan $\mathrm{CaCO}_{3}$ 0,01 M Dipipet
100 ml larutan $\mathrm{CaCO}_{3}$ kedalam labu erlenmeyer. Ditambahkan $1-2 \mathrm{ml}$ buffer $\mathrm{pH} 10$ kemudian ditambahkan indicator EBT.Dititrasi dengan $\mathrm{Na}_{2}$ EDTA sampai terjadi perubahan warna dari merah anggur menjadi biru keunguan konstan.

c. Penetapan kesadahan Total Dimasukkan $100 \mathrm{ml}$ sampel air sumur ke dalam Erlenmeyer. Kemudian ditambahkan dengan

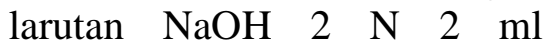
kemudian ditambahkan seujung sendok indikator Murexide. Selanjutnya Dititrasi dengan menggunakan larutan standar EDTA 0,01 M sampai terjadi perubahan warna merah violet menjadi keunguan konstan (diulang sebanyak 3 kali). Mencatat volume rata-rata EDTA yang digunakan.

Analisa Data

Analisa data yang terkumpul kemudian diuji secara statistik dengan uji Anova (Analysis of Variance) untuk mengetahui ada tidaknya perbedaan yang signifikan terhadap hasil pemeriksaan kesadahan kalsium air yang didihkan dengan beberapa tahapan waktu yang berbeda.

\section{HASIL}

Berdasarkan penelitian yang telah dilakukan di laboratorium Kimia Analitik Jurusan Analis Kesehatan Politeknik Kesehatan Makassar, diperiksa sampel sebanyak 3 sampel pada tanggal 11 Februari 22 Maret 2019, diperoleh hasil sebagai 
Tabel 1. Hasil Pemeriksan Kesadahan Kalsium Pada Air Sumur Gali Dikecamatan Bantimurung Kabupaten Maros Setelah Dilakukan Variasi Lama Pemanasan.

\begin{tabular}{|c|c|c|c|}
\hline No. & $\begin{array}{c}\text { Kode } \\
\text { Sampel }\end{array}$ & $\begin{array}{l}\text { Variasi Waktu } \\
\text { Pendidihan } \\
\text { (Menit) }\end{array}$ & $\begin{array}{c}\text { Hasil Penetapan } \\
\text { Kesadahan Kalsium } \\
(\mathrm{mg} / \mathrm{L})\end{array}$ \\
\hline \multirow{5}{*}{1} & \multirow{5}{*}{ A } & 0 & 34,56 \\
\hline & & 2 & 30,24 \\
\hline & & 4 & 29,52 \\
\hline & & 6 & 28,8 \\
\hline & & 8 & 23,76 \\
\hline \multirow{4}{*}{2} & \multirow{4}{*}{$\mathrm{B}$} & 0 & 32,4 \\
\hline & & 2 & 30,24 \\
\hline & & 4 & 28,8 \\
\hline & & 6 & 28,08 \\
\hline \multirow{6}{*}{3} & \multirow{6}{*}{$\mathrm{C}$} & 8 & 27,36 \\
\hline & & 0 & 32,4 \\
\hline & & 2 & 31,69 \\
\hline & & 4 & 28,8 \\
\hline & & 6 & 27,36 \\
\hline & & 8 & 23,76 \\
\hline
\end{tabular}

Sumber : Data Primer Maret 2019

Tabel 2. Hasil Uji Anova Pengaruh Lama Pemanasan Terhadap Nilai Kesadahan Kalsium Air Sumur Gali di Kec. Bantimurung Kab. Maros

\begin{tabular}{cccccc}
\hline Sumber Variasi & Db & JK & KT & F Hit & $\begin{array}{c}\text { F Tabel } \boldsymbol{\alpha} \\
(\mathbf{0 , 0 5})\end{array}$ \\
\hline Perlakuan & 4 & 110,830 & 27,708 & 19,07 & 3,48 \\
\hline Sisa & 10 & 14,72 & 1,453 & & \\
\hline Total & 14 & 125,36 & & & \\
\hline
\end{tabular}

Hasil analisis Kesadahan kalsium diperoleh F Hitung $(19,07)>$ F Tabel $(3,48)$ jadi $\mathrm{H \alpha}$ diterima artinya terdapat pengaruh yang signifikan untuk variasi waktu pemanasan terhadap nilai kesadahan kalsium pada air sumur gali di Kecamatan Bantimurung Kabupaten Maros. 


\section{PEMBAHASAN}

Air adalah salah satu kebutuhan primer manusia yang kedua setelah udara untuk keperluan hidup. Dalam memenuhi kebutuhan manusia, air harus memenuhi standar kualitas salah satunya dari aspek kimia yaitu kesadahan.

Tingkat kesadahan kalsium yang tinggi dalam air dapat menyebabkan terbentuknya kerak pada dinding pipa yang menyebabkan penyempitan penampang pipa, juga terbentuknya kerak pada dinding peralatan memasak sehingga menyebabkan pemakaian bahan bakar yang lebih banyak dan menyebabkan pemakaian sabun yang tinggi.

Tingkat Kesadahan kalsium menurut Peraturan Menteri Kesehatan RI Nomor 416/MENKES/PER/IX/1990 tentang syarat-syarat kualitas air bersih, tingkat kesadahan kalsium maksimum yaitu: $500 \mathrm{mg} \mathrm{Ca/l}$, Peraturan Menteri Kesehatan RI Nomor 907/MENKES/SK/VII/2002 tentang syarat-syarat pengawasan air minum yaitu $100 \mathrm{mg} \mathrm{CaCO}_{3} / \mathrm{l}$ dan World Health Organisation (WHO) Inter Regional Study Group yaitu : $75-150 \mathrm{mg} / \mathrm{l}$

Air sadah digolongkan menjadi dua jenis berdasarkan jenis anion yang diikat oleh kation $\left(\mathrm{Ca}^{2+}\right.$ dan $\left.\mathrm{Mg}^{2+}\right)$, yaitu air sadah sementara dan air sadah tetap. Air yang mengandung kesadahan sementara yakni garam $\mathrm{Ca}\left(\mathrm{HCO}_{3}\right)_{2}$ dan $\mathrm{Mg}\left(\mathrm{HCO}_{3}\right)_{2}$ jika dipanaskan maka akan membentuk senyawa $\mathrm{CaCO}_{3}$ dan $\mathrm{MgCO}_{3}$. Garam $\mathrm{MgCO}_{3}$ mempunyai kelarutan yang lebih besar dalam air panas, namun semakin rendah temperaturnya kelarutannya semakin kecil bahkan menjadi tidak larut dan dapat mengendap. Garam $\mathrm{CaCO}_{3}$ kelarutannya lebih kecil dari $\mathrm{MgCO}_{3}$, sehingga pada air panas sebagian $\mathrm{CaCO}_{3}$ mengendap dan pada air yang telah dingin pengendapannya lebih banyak lagi. Terjadinya endapan ini memungkinkan hasil perhitungan kesadahan menjadi lebih rendah.

Komposisi mineral dalam air minum yang bersumber dari air permukaan (dataran tinggi dan rendah) didominasi oleh unsur kalsium dan magnesium. Kadar kalsium inilah yang diduga dapat mengakibatkan hipereksresi kalsium urine dan supersaturasi (kristalisasi $\mathrm{O}_{2}$ oksalat) yang merupakan proses awal terjadinya pengendapan batu saluran kemih maka dari itu dilakukan percobaan pemanasan terhadap air sumur gali yang dapat menurunkan tingkat kesadahan sementara pada air sumur gali tersebut.

Pada penelitian ini lama variasi waktu pendididihan diteliti apakah terdapat pengaruh terhadap hasil pemeriksaan kesadahan kalsium, air atau tidak terdapat pengaruh. Penelitian ini dilakukan dengan menggunakan variasi waktu pendidihan yang berbeda yaitu pendidihan selama $0,2,4,6$, dan 8 menit.

Hasil pemeriksaan kesadahan kalsium dangan pendidihan selama 0 menit, 2 menit, 4 menit, 6 menit, 8 menit di uji secara statistik dengan menggunakan uji Anova untuk mengetahui apakah terdapat pengaruh yang signifikan atau tidak antara variasi waktu pendidihan tersebut. 
Berdasarkan data yang diperoleh dan setelah dilakukan uji statistik dengan uji Anova oneway menunjukkan bahwa hasil penetapan kesadahan Kalsium yaitu Dari data hasil penelitian di atas maka diperoleh bahwa $\mathrm{F}_{\text {Hitung }}(19,07)>$ $\mathrm{F}_{\text {Tabel }}(3,48)$ jadi $\mathrm{H} \alpha$ diterima artinya terdapat pengaruh yang signifikan untuk variasi waktu pemanasan terhadap nilai kesadahan kalsium pada air sumur gali.

Dari ketiga sampel yang diambil dan diperiksa pada sumur gali yang terdapat di Kec. Bantimurung, mulai dari kesadahan total setelah dilakukan beberapa variasi waktu pendidihan yaitu 0 menit, 2 menit, 4 menit, 6 menit, dan 8 menit mendapatkan hasil yaitu, kesadahan $\mathrm{Ca}$ yaitu 23,76 - 34,56 $\mathrm{mg} / \mathrm{l}$. Masing-masing masih dalam batas maksium yang diperbolehkan tentang syarat air bersih dan masih memenuhi standar kualitas air minum yang telah ditetapkan meskipun menurut Peraturan Menteri Kesehatan RI Nomor 907/MENKES/SK/VII/2002 tentang syarat-syarat pengawasan air minum yaitu $100 \mathrm{mg} / \mathrm{L}$, ketiga sampel yang telah diperiksa melebihi standar maksimum namun menurut Peraturan Menteri Kesehatan RI Nomor 416/MENKES/PER/IX/1990 tentang syarat-syarat kualitas air bersih yaitu $500 \mathrm{mg} / \mathrm{L}$ dan World Health Organisation (WHO) Inter Regional Study Group yaitu 75-153 mg.L, ketiga sampel air sumur tersebut masih dalam standar maksimum yang diperbolehkan sehingga air dari ketiga sumur tersebut dapat dijadikan sumber air bersih.

\section{KESIMPULAN}

Berdasarkan hasil penelitian ditarik kesimpulan yaitu semakin lama waktu pendidihan yang dilakukan maka akan semakin menurunkan tingkat kesadahan pada air sumur gali tersebut.

\section{SARAN}

Kepada masyarakat yang menggunakan air sumur gali agar memperhatikan lama pemanasan air karena semakin lama waktu pendidihan yang dilakukan maka akan semakin menurunkan tingkat kesadahan pada air sumur gali tersebut

\section{DAFTAR PUSTAKA}

Anonim. 1989. Kimia Air untuk Sekolah Menegah Analis Kesehatan. Jakarta : DEPKES RI.

Anonim. 2002. Keputusan Menteri Kesehatan Republik Indonesia NOMOR907/MENKES/SK/VII/ 2002. www.airminumisiulang.c omDiakses Jumat, 17 Mei 2013.

Anonim, 2002. Syaratsyarat dan pengelolaan air min um

http://www.ampl.or.id/digilib/r ead/syarat-syarat-dan-

pengawasan-kualitas-airminum/ Diakses pada Sabtu, 18 Mei 2013

Anonim, 2007. Kalsium. http://ms.wikipedia.org/kalsium . Diakses pada Jumat, 17 Mei 2013

Anonim, 2011. Air Bagi Kehidupan. http://vo2indonesia.wordpress.c om /tag/fungsi-air-yang-utama/ 
Diakses pada Sabtu, 18 Mei 2013

Anonim. 2013. Kesadahan Air. www.wikipedia.org/wiki/kesad ahanair. Diakses Kamis, 16 Mei 2013

Anonim. 2013. Siklus Air. www.wikipedia.org/wiki/siklus air. Diakses Kamis, 16 Mei 2013

Efendi, Hefni. 2003. Telaah Kualitas Air. Yogyakarta: Kanisius.

Muntu, R. 2003. Air dan Kesehatan. Makassar : Depkes R.I. Politeknik Kesehatan Jurusan Kesehatan Lingkungan Makassar

Rukaesih A, $2004 \quad$ Kimia Lingkungan. Yogyakarta : Andi.

Said IN, 2010 Kesadahan Air, Jakarta

Slamet, J. S. 2009. Kesehatan Lingkungan. Yogyakarta : Gadja Mada University Press.

Suripin. 2004. Pelestarian Sumber Daya Tanah dan Air. Yogyakarta : Andi.

Weiner, ER. 2011. Aplication of Environmental Aquatic Chemistry A Practical Guide : Second Edition. 